referred the patient here reported to Dr. J. Badenoch at the Radcliffe Infirmary, and also Drs. Richards, Aherne, and Woods for pathological reports quoted in the text. Among those who provided information and helpful discussion we mention with gratitude the late Professor P. Fourman, Dr. B. E. C. Nordin, Dr. C. G. Woods, Dr. S. I. Roth, and, most particularly, Professor S. W. Stanbury and Dr. J. T. Potts jun.

\section{REFERENCES}

Albright, F., Butler, A. M., and Bloomberg, E. (1937). American foumal of Diseases of Childhood, 54, 529.

Albright, F., and Reifenstein, E. C., jun. (1948). The Parathyroid Glands and Metabolic Bone Disease. Baltimore, Williams \& Wilkins.

Arnaud, C., Rasmussen, H., and Anast, C. (1966). Fournal of Clinical Investigation, 45, 1955.

Ball, J. (1963). In Bone Metabolism in Relation to Clinical Medicine, edited by H. A. Sissons, p. 31. London, Pitman Medical.

Bennett, T. I., Hunter, D., and Vaughan, J. M. (1932). Quarterly foumal of Medicine, 1, 603.

Bernstein, D., Kleeman, C. R., Dowling, J. T., and Maxwell, M. H. (1962). Archives of Internal Medicine, 109, 43.

Bogdonoff, M. D., Woods, A. H., White, J. E., and Engel, F. L. (1956). American fournal of Medicine, 21, 583.

Boyce, D., and Jowsey, J. (1966) Proceedings of the Staff Meetings of the Mayo Clinic, 41. 836.

Case Records of the Massachusetts General Hospital (1963). New England Fournal of Medicine, 268, 943.

Cotton, S. G., Bloom, A., and Dent, C. E. (1969). Proceedings of the Royal Society of Medicine, 62, 737.

Davies, D. R., Dent, C. E., and Watson, L. (1968). British Medical fournal, 3, 395.

Davies, D. R., Dent, C. E., and Willcox, A. (1956). British Medical Fournal, 2, 1133.

Dent, C. E. (1956). British Medical fournal, 1, 230.

Dent, C. E. (1962). British Medical fournal, 2, 1419, 1425.

Dent, C. E., and Watson, L. (1968). Lancet, 2, 662.

Evanson, J. M. (1966). Clinical Science, 31, 63.

Fourman, P., and Haapanen, E. (1964). Schweizerische Medizinische Wochenschrift, 94, 886

George, J. M., Rabson, A. S., Ketcham, A., and Bartter, F C. (1965).

Quarterly fournal of Medicine, 34, 291.
Glanville, H. J., and Bloom, R. (1965). British Medical fournal, 2, 26.
Golden, A., Canary, J. J., and Kerwin, D. M. (1965). American fournal of Medicine, 38, 562 .

Harrison, H. E., and Harrison, H. C. (1964). Metabolism, 13, 952.

Harrison, H. C., Harrison, H. E., and Park, E. A. (1958). American Fournal of Physiology, 192, 432.

Harrison, M., and Nordin, B. E. C. (1960). British Medical fournal, 1, 245.

Hodgkinson, A., and Edwards, N. A. (1963). British fournal of Urology, $35,445$.

Holst, J. E. (1927). Acta Medica Scandinavica, 66, 74.

Jonxis, J. H. P. (1961). Fournal of Pediatrics, 59, 607

Lamki, L. (1969). Lancet, 1, 888.

Ludwig, G. D., Kyle, G. C., and de Blanco, M. (1967). American fournal of Medicine, 43, 136.

McIntosh D. A., Peterson, E. W., and McPhaul, J. J., jun. (1966) Annals of Internal Medicine, 65, 900 .

McPhaul, J. J., jun., McIntosh, D. A., Hammond, W. S., and Park, O. K. (1964). New England Fournal of Medicine, 271, 1342.

Mather, H. G. (1953). British Medical Fournal, 2, 424.

Mickerson, J. N. (1960). British Medical fournal, 1, 529.

Mixter, C. G., jun., Keynes, M., and Cope, O. (1962). New England fournal of Medicine, 266, 265.

Morgan, D. B., Paterson, C. R., Woods, C. G., Pulvertaft, C. N., and Fourman, P. (1965). Lancet, 2, 1089.

Morii, H., and DeLuca, H. F. (1967). American fournal of Physiology, $213,358$.

Nadarajah, A., Joplin, G. F., Taylor, S., and Williams, E. D. (1969). Proceedings of the Royal Society of Medicine, 62, 709.

Nordin. B. E. C. (1961). Advances in Clinical Chemistry, 4, 275

Page, F. (1954). Archives of the Middlesex Hospital, 4, 215.

Plough, I. C., and Kyle, L. H. (1957). Annals of Internal Medicine, 47, 590.

Prineas, J. W., Mason, A. S., and Henson, R. A. (1965). British Medical fournal, 1, 1034.

Rasmussen, H., DeLuca, H. F., Arnaud, C., Hawker, C., and von Stedingk, M. (1963). Fournal of Clinical Investigation, 42, 1940.

Roth, S. I. (1968). Personal communication.

Stanbury, S. W. (1968) Personal communication.

Stanbury, S. W., Lumb, G. A., and Nicholson, W. F. (1960). Lancet, 1, 793.

Steendijk, R. (1964). Acta Paediatrica, 53, 105.

Wills, M. R., Pak, C. Y. C., Hammond, W. G., and Bartter, F. C. (1969). American fournal of Medicine, 47, 384.

Woods, C. G., Morgan, D. B., Paterson, C. R., and Gossman, H. H. (1968). Fournal of Pathology and Bacteriology, 95, 441.

\title{
Enuresis and the Electric Alarm: Study of 200 Cases
}

\author{
W. I. FORSYTHE, ${ }^{*}$ M.D., F.R.C.P.ED.; A. REDMOND, † M.R.C.P.I.
}

\begin{abstract}
Qummary: Of 200 children with persistent enuresis $66 \%$ were cured after treatment with an electric alarm over a 30-week period. It is suggested that treatment may be discontinued after the child has been dry for four weeks, that if continued for longer than 16 weeks treatment is unlikely to produce a cure, and that a two-year follow-up period is necessary before a cure can be accepted.
\end{abstract}

\section{Introduction}

Nocturnal enuresis may be defined as urinary incontinence occurring during sleep in children aged 3 years or older in the absence of congenital or acquired defects of the central nervous or genitourinary tract. It is one of the most common and harassing conditions in childhood. Not only does it require patience on the part of the doctor treating the child but the whole family may be involved. The patient as he grows older realizes that he is different and finds that he is unable to take part in activities which necessitate staying away from home -for example, camping, etc. The mother in her anxiety and

* Consultant Paediatrician.

†Senior Registrar. The Enuretic Clinic, The Royal Belfast Hospital for Sick Children,
Belfast BT12 6BE. resentment has difficulty in not transferring her despair to the child after nights of changing and days of washing bedclothes. In Britain during the second world war people's attitude towards enuresis changed. With the mass evacuation of children to urban areas it was realized that enuresis was much more common than previously suspected. Emotional stress was advanced as a major cause, and this resulted in the introduction of psychotherapeutic methods of treatment followed later by drugs and conditioning methods.

Drug therapy has not proved successful, and the results from it are not as good as those obtained with conditioning methods. Young (1965) had a cure rate of 36\% with drugs; he found that it took twice as long to obtain a cure and that relapse was twice as common as with conditioning methods. The results with the latter have been most encouraging and can explain the increased enthusiasm for this treatment. It is, however, difficult to subject the method to a controlled trial. Kahane (1955), attempted to do this by comparing patients treated by means of an electric alarm with those on the waiting-list and found little difference between the groups. Forrester, Stein, and Susser (1964) carried out a controlled trial with the alarm and with amphetamine; they found that amphetamine did not accelerate cure and that the alarm was more effective. 
At present at least 11 enuresis alarm sets are available, ranging in price from $£ 317 \mathrm{~s}$. $6 \mathrm{~d}$. to $£ 810 \mathrm{~s}$. Their high price and reports of a home-made buzzer by Metcalfe (1959) led to the development of an apparatus by Taylor (1963) costing as little as a guinea.

\section{Material}

The series comprised 200 children who were persistent bed-wetters ( 132 boys and 68 girls). All were subjected to a routine clinical examination, and a midstream specimen of urine was cultured for organisms and examined for pus cells. None had an infected urine. An organic cause for the enuresis could not be excluded without intravenous pyelography and micturition cystography. It is now our routine to wait until the patient has had a course of drug therapy and treatment with the alarm bell before arranging radiological investigations.

\section{Results}

The number of wet nights a week at the beginning of treatment is shown in Table I. The children were treated for

TABLE I.-Number of Wet Nights a Week for Cures, and Failures Expressed as a Percentage of Cures

\begin{tabular}{|c|c|c|c|c|c|c|c|c|}
\hline No. of wet nights a week: & 1 & 2 & 3 & 4 & 5 & 6 & 7 & Total \\
\hline failures & & $\begin{array}{c}2 \\
33 \%\end{array}$ & $\begin{array}{c}5 \\
28 \%\end{array}$ & $\begin{array}{c}8 \\
27 \%\end{array}$ & $28 \%$ & $\begin{array}{r}7 \\
50 \%\end{array}$ & $\begin{array}{l}105 \\
33 \%\end{array}$ & 34 \\
\hline
\end{tabular}

periods of 4 to 30 weeks and were followed up for one to three years. The number of cases, cures, and failures according to sex are shown in Table II. The cure rate in each sex was $66 \%$.

TABLE II.-Number of Cases, Cures, and Failures According to $S \in x$

\begin{tabular}{|c|c|c|c|c|}
\hline & Sex & & Boys & Girls \\
\hline $\begin{array}{l}\text { No. of cases } \ldots \\
\text { No. of cures } \ldots \\
\text { No. of failures }\end{array}$ & $\begin{array}{ll}\cdots & \\
\because & \\
\cdots & \end{array}$ & $\begin{array}{ll} & \\
\cdots & \end{array}$ & $\begin{array}{l}132 \\
87(66 \%) \\
45(34 \%)\end{array}$ & $\begin{array}{l}68 \\
45(66 \%) \\
23(34 \%)\end{array}$ \\
\hline
\end{tabular}

Boys aged 11 to 15 had a similar cure rate to those aged 5 to 10 , while girls aged 11 to 15 had a slightly better cure rate than those under 10 -that is $69 \%$ compared with $60 \%$. The number of cures with percentages as well as the total percentage cures at two-weekly intervals from 2 to 30 weeks is shown in Table III. In most children a cure may be expected who were cured for one to three years are given in Table V. At six months 28 had relapsed and between 6 and 12 months another two relapsed. Of these, 17 were cured after a second

TABLE V.-Cures, Relapses, and Period of Follow-Up
\begin{tabular}{l|c|c|c|c|c|c}
\hline & 12 Months & 18 Months & 24 Months & 30 Months & 36 Months & Total \\
\hline $\begin{array}{l}\text { Cures } \\
\text { Relapses }\end{array}$ & 10 & 8 & 16 & 10 & 88 & $\begin{array}{c}132 \\
30\end{array}$ \\
\hline
\end{tabular}

course of treatment but the remaining 13 were not improved. No relapses occurred after a year's follow-up.

Failures.-In this series of 200 patients treatment was of no value in 45 , being abandoned by 2 after three months, by 3 after four months, by 15 after six months, and by 25 after nine months. Seven children failed to waken with the alarm and 12 would not co-operate. In four cases the treatment was abandoned because the alarm kept everyone awake.

\section{Discussion}

The original apparatus used for the treatment of enuresis was designed by Pfaundler (1904). Since then numerous articles have given results of cure varying from 30 to $100 \%$ (Young, 1969). In this series the cure rate for both sexes was $66 \%$.

Little attempt has been made to predict the optimum period of dryness before treatment is discontinued and how long the child should be followed up before cure is finally accepted. Freyman (1963) and Young (1965) accepted two weeks' dryness and Taylor (1963) three weeks' dryness as evidence of cure. Relapse is less likely if treatment is discontinued after four weeks' dryness (Table IV). Most children in this series were followed up for more than two years and all for more than one (Table V). It appears that after a year's remission there is little likelihood of relapse. Recently we have had four patients not included in this series relapsing in the second year, and it is now our routine to follow up such patients for at least two years.

Study of the literature did not show how long treatment should be continued. In this series if the child was not cured after 16 weeks his chance of cure with further treatment was small (Table III). It is possible that cures occurring after 22 weeks' treatment were spontaneous cures and not due to the conditioning method. Gillison and Skinner (1958) suggested that the cure rate in older children is not as high as in younger children. In this series there was little difference between the

TABLE III. - Number of Cures with Percentages as Well as the Total Percentage Cures at Two-Weekly Intervals

\begin{tabular}{|c|c|c|c|c|c|c|c|c|c|c|c|c|c|c|c|c|c|c|}
\hline & & & ff weeks : & 2 & 4 & 6 & 8 & 10 & 12 & 14 & 16 & 18 & 20 & 22 & 24 & 26 & 28 & 30 \\
\hline $\begin{array}{l}\text { No. of cures } \ldots \\
\text { Percentage cures per two weeks } \\
\text { Total Percentage cures.. }\end{array}$ & $\because$ & $\begin{array}{l}\cdots \\
\cdots\end{array}$ & 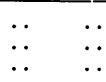 & $\begin{array}{l}8 \\
4 \\
4\end{array}$ & $\begin{array}{l}22 \\
16 \\
20\end{array}$ & $\begin{array}{r}19 \\
9 \cdot 5 \\
28 \cdot 5\end{array}$ & $\begin{array}{l}19 \\
9 \cdot 5 \\
39\end{array}$ & $\begin{array}{r}12 \\
6 \\
45\end{array}$ & $\begin{array}{r}14 \\
7 \\
52\end{array}$ & $\begin{array}{r}4 \\
2 \\
54\end{array}$ & $\begin{array}{r}6 \\
3 \\
57\end{array}$ & $\begin{array}{c}1 \\
0 \cdot 5 \\
57 \cdot 5\end{array}$ & $\begin{array}{c}0 \\
0 \\
57 \cdot 5\end{array}$ & $\begin{array}{c}0 \\
0 \\
57 \cdot 5\end{array}$ & $\begin{array}{c}2 \\
1 \\
58 \cdot 5\end{array}$ & $\begin{array}{r}3 \\
1 \cdot 5 \\
61 \cdot 5\end{array}$ & $\begin{array}{c}5 \\
2 \cdot 5 \\
64\end{array}$ & $\begin{array}{r}7 \\
3.5 \\
66\end{array}$ \\
\hline
\end{tabular}

in 16 weeks, but after this period the likelihood of cure is small. The number of cures and relapses after one, two, three, and four weeks of dryness before treatment was discontinued is shown in Table IV. The results of follow-up of children

TABLE IV.-Number of Cures and Relapses After One, Two, Three, and Four Weeks of Dryness

\begin{tabular}{|c|c|c|c|c|c|c|c|}
\hline & & & & 1 week & 2 weeks & 3 weeks & 4 weeks \\
\hline $\begin{array}{l}\text { Cures ... } \\
\text { Relapses }\end{array}$ & $\because$ & 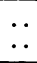 & $\because$ & $\begin{array}{l}69 \\
94\end{array}$ & $\begin{array}{l}79 \\
65\end{array}$ & $\begin{array}{r}100 \\
43\end{array}$ & $\begin{array}{r}132 \\
17\end{array}$ \\
\hline Total . & . & . & $\ldots$ & 163 & 144 & 143 & 149 \\
\hline
\end{tabular}

cure rate in children aged 11 to 15 and in those aged 5 to 10 . Gillison and Skinne: (1958) found that $59 \%$ of patients wetting every night became dry after five weeks' treatment as compared with $35 \%$ of intermittent wetters. The likelihood of cure does not seem to depend on the number of nights a week the child is wetting before treatment is begun (Table I).

Failures.-As in so many chronic diseases of childhood, parental co-operation plays an important part in the management and successful outcome of the child's complaint. In enuretic children the most common reasons for failure of treatment are that the parents will not co-operate, the child comes from an overcrowded home, or the apparatus is not 
used properly. Freyman (1963) reported how older children often sabotaged the parents' efforts to make them use the apparatus, and, in others, the mother's anxiety would be transferred to her child, who would then refuse to use the apparatus. In this series there were 23 such failures (11.5\%)namely, 12 children would not co-operate, in four cases the alarm kept everyone awake, and seven children failed to awaken with the alarm. Of the 12 who would not co-operate, 10 refused point-blank to sleep with the apparatus. Some authors would exclude children who refused, but we feel that all cases should be included. The failure rate compares favourably with that obtained by other authors-namely Wickes (1958) $26 \%$, Taylor (1963) 19\%, and Young (1965) 35\%.

Relapses.-In this series 30 patients relapsed-28 within six months of discontinuing treatment and 2 between 6 and 12 months. Of these 30 patients, 17 were cured by a second course of treatment. The overall relapse rate was $6.5 \%$.

Complications. - A rash consisting of red papules or punched-out ulcers has been described by Gillison and Skinner (1958), Borrie and Fenton (1966), and Greaves (1969). These have been thought to be due to electrolysis of sodium chloride in the urine with the production of sodium hydroxide at the cathode. One of the following may be the cause: too small a quantity of urine leaking on to the bed and thus failing to set off the alarm, a run-down battery, or the bell failing to waken the patient. In this series no ulcers occurred: it has been suggested that buzzer ulcers are more likely to occur with metal-foil electrodes. In our experience metal-foil electrodes are unsatisfactory, of ten disintegrating after 8 to 10 weeks' use, and for this reason we have not used them for several years. Freyman (1963) stated that foil-type sheets do not activate the bell as quickly as the wire-type.

\section{REFERENCES}

Borrie, P., and Fenton, J. C. B. (1966). British Medical fournal, 2, 151 Freyman, R. (1963). Journal of Child Psychology and Psychiatry and Allied Disciplines, 4, 199.

Forrester, R. M., Stein, Z., and Susser, M. W. (1964). Developmental Medicine and Child Neurology, $6,158$.

Gillison, T. H., and Skinner, J. L. (1958). British Medical fournal, 2 , 1268

Kahane, M. (1955). American Psychologist, 10, 369

Greaves, M. W. (1969). Archives of Diseases in Childhood, 44, 285.

Metcalfe, J. B. (1959). British Medical fournal, 2, 1488.

Pfaundler, M. (1904). Verhandlungen der Gesellschaft für Kinderheilkunde, 21, 219 .

Taylor, I. O. (1963). Medical Officer, 110, 139.

Wickes, I. G. (1958). Archives of Diseases in Childhood, 33, 160

Young, G. C. (1965). Developmental Medicine and Child Neurology, 7 557.

Young, G. C. (1969). British Fournal of Hospital Medicine, 2, 628.

\section{Medical Memoranda}

\section{Severe Hypercalcaemia from Hyperthyroidism with Unusual Features}

British Medical fournal, 1970, 1, 213-214

Mild disturbance of calcium metabolism in hyperthyroidism is well recognized but severe hypercalcaemia is rare. We report here a further case of pronounced hypercalcaemia from hyperthyroidism with several unusual features.

\section{Case Report}

The patient, a 50-year-old nursing sister, presented in September 1967 with a six-month history of weakness, nausea, vomiting, and intermittent epigastric pain unrelated to meals, with loss of appetite and of 4 st. $(25 \mathrm{~kg}$.) in weight. Because of progressive breathlessness on exertion she could walk only 10 yards (9 metres) on the flat. Her previous illnesses included migrainous vomiting as a child and intermittent attacks of nausea, vomiting, and epigastric discomfort for the previous four years; a barium meal examination in 1964 showed nothing abnormal. She had rheumatic fever when aged 16 and 26, but there had been no limitation of her exercise tolerance until latterly.

Her present illness had been investigated in June 1967 elsewhere by barium studies, cholecystogram, and urography, all of which gave normal results, and in July she was referred to a psychiatric day hospital, from which she discharged herself after a few weeks.

On examination she was ill, pale, and dehydrated. She was pyrexial (99-101 ${ }^{\circ} \mathrm{F}$; $37 \cdot 2-38.3^{\circ} \mathrm{C}$.) with a tachycardia of 130 and a soft mid-diastolic apical murmur. There was pronounced upper abdominal tenderness and generalized muscle weakness and wasting.

Initial investigations failed to reveal a definite diagnosis: haemoglobin 9.4 g./100 ml., E.S.R. $80 \mathrm{~mm}$./hour (Westergren),
W.B.C. $6,900 /$ cu.mm. with normal differential, microcytic red cells, and blood urea nitrogen $38 \mathrm{mg} . / 100 \mathrm{ml}$. Electrolytes: $\mathrm{Na} \mathrm{146,} \mathrm{K}$ $2.2, \mathrm{Cl} 88$, alkali reserve $39 \mathrm{~m} . \mathrm{Eq} / 1$. Bilirubin $0.7 \mathrm{mg} . / 100 \mathrm{ml}$., alkaline phosphatase 24 K.A. units $/ 100 \mathrm{ml}$. Serum aspartate aminotransferase 85 units and serum alanine aminotransferase $\mathbf{2 1 0}$ units (normal range 20-110 units.) Flocculations and turbidities normal. Plasma protein total $7.1 \mathrm{~g} . / 100 \mathrm{ml}$. (albumin 2.9 , globulin $\alpha_{1} 0.6, \alpha_{2} 1.4, \beta 0.7, \gamma 1.5 \mathrm{~g} . / 100 \mathrm{ml}$ ). Midstream specimen of urine showed pyuria and coarse granular casts with 0.05 g. $/ 100$ $\mathrm{ml}$. of protein. Examination of faeces showed persistent occult bleeding. Gastroscopy (21 September) revealed normal gastric mucosa with normal motility, and a barium meal examination showed only a slowly emptying stomach. Therapy was instituted with intravenous fluids, phenothiazines, ampicillin, and, later, potassium chloride by mouth when vomiting had stopped.

At this stage gross hypercalcaemia was present (corrected levels* 14.9-15.8 mg./100 ml.), with a normal serum phosphate (2.9$3.4 \mathrm{mg} . / 100 \mathrm{ml}$.). Bleeding and clotting times were normal and there was no shortening of the Q-T interval of the E.C.G., though non-specific $T$-wave inversion was noted. The commoner causes of hypercalcaemia were considered. There was no history of excessive alkali, milk, or vitamin-D ingestion, and protein electrophoresis showed no abnormal proteins. The raised alkaline phosphatase suggested hyperparathyroidism, but the subsequent clinical course and steroid suppression negated this diagnosis. The protein electrophoresis and high E.S.R. with negative Mantoux reaction (to 100 units of old tuberculin) were suggestive of sarcoidosis, but a Kveim test was subsequently shown to be negative. The clinical picture, anaemia, high E.S.R., and persistent occult gastrointestinal bleeding raised the possibility of a gastrointestinal neoplasm.

It was decided, in view of the risk of serious renal damage, to try the diagnostic and therapeutic effect of steroids (prednisolone $80 \mathrm{mg}$./day). The result was dramatic, clinically and biochemically (see Chart). 